\title{
Sulfur as a parameter in the suitability assessment of gangue from coal mining for reclamation of opencast excavation, taking into the requirements regarding protection of the soil
}

\author{
Beata Klojzy-Karczmarczyk ${ }^{1 a}$, Janusz Mazurek ${ }^{1}$ and Jacek Mucha ${ }^{2}$ \\ ${ }^{1}$ The Mineral and Energy Economy Research Institute of the Polish Academy of Sciences, Krakow, Poland \\ ${ }^{2}$ AGH University of Science and Technology, Krakow, Poland
}

\begin{abstract}
In the process of mining coal considerable amounts of waste material are generated from which it is possible to produce aggregates which could find application in the reclamation of opencast excavations. One of the basic characteristic parameters which may be used to assess the suitability of aggregates for filling reclaimed opencast excavation is sulfur. Total and leachable forms of sulfur content from gangue samples were analyzed in the study. It has been shown that it is possible to select aggregates which are safe for the environment when the main assessment criterion was the percentage of sulfur in the aggregates and sulfate concentration in leaching tests. The research confirmed the role of sulfur as the most important and characteristic parameter which determines where and in what specific conditions the use of gangue or mining waste may be possible. Studies of sulfur content in the samples should be carried out with sufficient periodicity and in a manner enabling to obtain most reliable results which would refer to the entire batch of material. The statistical evaluation makes it possible to estimate to what extent the obtained results of sulfur content in the samples are close to actual values for the entire mass of the material.
\end{abstract}

\section{Introduction}

The process of extraction and processing of coal produces significant amounts of waste material. It is mainly gangue removed during the preparation of the deposit and the waste material generated by the extraction and processing of run-of-mine coal. An important issue is the proper management of waste material including the requirements for the prevention of pollution of soil and water environment. These materials may be treated as minerals accompanying the coal deposits [1]. It is possible and practiced to use them in a variety of economic processes, including production of aggregates for civil engineering, hydro-engineering, road engineering and as a raw material for the production of building materials, or as material for underground backfilling and reclamation of degraded areas [1 - 4]. These materials can be used also in the process of filling open-pit excavations. Filling the post-exploitation excavation with external material is the primary stage of the technical phase of the reclamation process in openpit mining [5]. Waste materials for which there is no use, become mining waste, classified as group 01 and most often neutralized by storage $[6,7]$.

Both waste rock, considered as raw material and material deemed mining waste may be used for reclamation of excavations by filling. There is a number of legal conditions in force, application

\footnotetext{
a Corresponding author: beatakk@min-pan.krakow.pl
}

of which allows for safe filling of the excavation pit. It should be noted that there are frequent changes of regulations regarding the possibility of using byproducts from coal mining to fill various types of excavations [6, $8-11]$. In each case it is necessary to conduct a wide analysis of possible use of mining waste from coal production or products based on waste rock for reclamation, which is a complex issue in relation to the soil and water conditions and to the location of the project. The relevant regulations provide limits of physicochemical parameters for mining waste, which if met - allow for considering the waste to be neutral to the environment. However, in regard to gangue as a product (aggregate), which is a side effect of coal production, and may be used in the process of filling various open-pit mines, no clear legal provisions relating to the determination of their safety for the environment are in force. The material may be considered safe for the environment, if it meets the stringent requirements for inert mining waste and demonstrates no negative impacts on the soil and water environment [11].

The analysis presented in the work, concerns gangue from Janina Mine in Libiąż, which is a side effect of coal production and is used for aggregate production. The conducted studies allow for drawing conclusions regarding the content of sulfur in the analyzed material and whether it is possible in this case to separate particular fractions of the aggregate, which will meet 
the requirements for the quality of inert waste in order to ensure safety for the soil and water environment.

\section{Limit values of the sulfur content}

The produced aggregate, depending on the source, contains varying amounts of mineral impurities, including elements commonly recognized as possibly contaminating the soil and water environment. One of the basic characteristic parameters, which can be used to assess the suitability of aggregates for use as a filling material for reclaimed open-pit mines is sulfur, which is released slowly from the sulfides present in the waste and is introduced to the water in the form of sulfates and can lead, in extreme cases, to pollution of the environment. There is a great number of information in the literature concerning the possibility of oxidation of sulfides and consequently the activation of sulfates from landfills, where the stored waste includes waste from coal mining [12 - 16]. The literature data indicates definitive variation in the sulfur content in the mining waste, also due to the presence of this element in the run-of-mine coal [6, 8, 10, 15 - 19]. In [3] different sulfur contents in the mining waste of Janina Mine are provided, where - depending on the place of its origination - the contents of this element ranges from 0.4 to $3 \%$.

It can be assumed that the perspective material for reclamation includes mining waste or gangue-based materials (aggregates) for which the total sulfur content is less than $1 \%$. Such a limit for inert mining waste may be adopted where the neutralizing potential ratio (defined as the ratio of neutralizing potential to the acidity potential) is greater than 3. Otherwise, one should adopt the limit of sulfur content at $0.1 \%$ [20]. The maximum content of sulfide sulfur in the mining waste defined this way allows for classifying it as inert waste or not.

\section{Methodology of the sulfur content analysis in the aggregates}

To investigate the variability of total sulfur content in the aggregates from the waste material from Janina Mine, 16 primary samples were collected (15 samples with a mass of about $200 \mathrm{~kg}$ each and one sample with a mass of about $100 \mathrm{~kg}$ ) (Fig. 1). Samples were taken for a year at intervals of 2-3 weeks. Sampling was conducted directly from the run-of-mine winning (mining waste rock) before its transport to the dumping ground. Therefore, the analyzed material originated directly from the mine's production.

Raw samples were sieved to 14 fractions in the range of 0 to $200 \mathrm{~mm}(0-6,6-8,8-10,10-16,16-20,20-25,25-$ $30,30-35,35-40,40-50,50-60,60-80,80-120,120-200$ $\mathrm{mm}$ ) and above $200 \mathrm{~mm}$. It has been proven that in the aggregate fractions (mining waste) of larger grains diameter, the total sulfur content is low enough that this material can be considered inert for the environment [21]. The key issue in this case was to determine the lower limit of the fraction of rock above which the average sulfur content does not exceed the limit value with risk of error small enough and possible for practical acceptance. Based on the study of the indicator of neutralizing potential, and in accordance with [22], the limit for sulfur content was set at $1 \%$. In order to verify the obtained results, samples called secondary samples were prepared in laboratory conditions through combining all fractions with a grain diameter exceeding $20 \mathrm{~mm}$ in the respective percentages. In practice, this has resulted in the removal of the finest fractions from each raw sample. For these samples studies of the content of the total and leachable forms of sulfur compounds were conducted. Leaching was conducted using static method (batch tests) on the basis of 1:10 tests (material: deionized water), according to [23]. Tests for the total sulfur content in the individual fractions of the raw samples were carried out using high-temperature method (Laboratory of Janina Mine). Examination of the total sulfur content in the secondary samples and of the sulfates in the solutions (Tab. 2) were conducted using the ICP OES method (AGH Hydrogeochemical Laboratory) and the spectrophotometric method (MEERI PAS Laboratory).

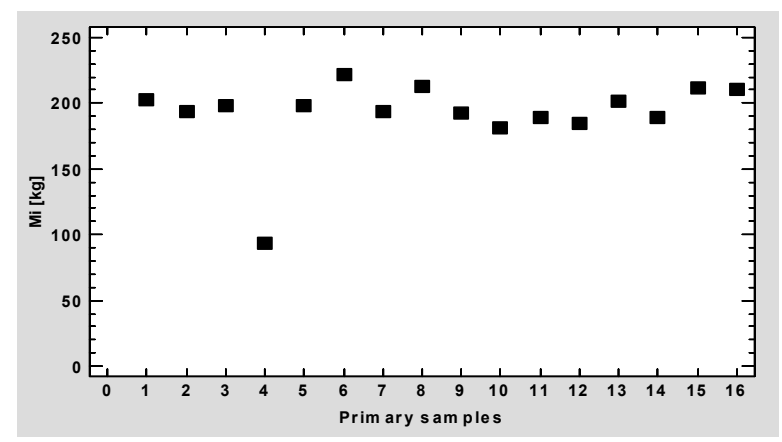

Figure 1. Plots of masses in the 16 primary samples (Mi - masses of the individual samples).

\section{Statistical analysis of the total sulfur content in the primary samples}

The samples of aggregates with weight of approx. $200 \mathrm{~kg}$ each obtained directly from the production were called the raw samples. In these samples the total sulfur content was determined in the individual fractions [21]. As the result of the estimation of the average sulfur content using the weighted average, in which the weight is the mass of the sample associated with the determination of sulfur content for each of the 15 grain fractions separated mechanically, the concept of the primary samples was introduced.

The basis of the statistical analysis constituted of the following:

- determination of total sulfur on dry matter $\left(\mathrm{S}_{\mathrm{t}}{ }^{\mathrm{d}}\right)$ in a 14 isolated fractions separately for each of the 16 raw samples [21],

- the sulfur content in the primary samples calculated as the weighted averages mass fraction (Fig. 3),

- the weighted averages of the sulfur content in each of the 14 fractions in the combined rock material of the 16 primary samples (Fig. 4). 
For all 16 primary samples the cumulative masses of the individual fractions of the collected material are in the range of $100-300 \mathrm{~kg}$ with the exception of the finest fraction $(0-6 \mathrm{~mm})$, the mass of which is significantly higher and is about $750 \mathrm{~kg}$ (Fig. 2).

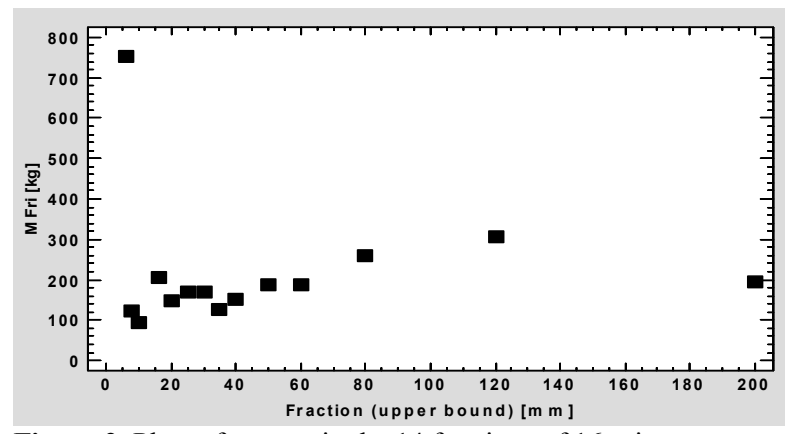

Figure 2. Plots of masses in the 14 fractions of 16 primary samples (M-Fri - masses of the individual fractions).

The sulfur content in the primary samples shows strong variation, from about $0.5 \%$ to about $4 \%$ (Fig. 3). Even greater variation is exhibited by the sulfur contents in the fractions of the material (cumulated for the 16 primary samples) ranging from $0.4 \%$ to over $5 \%$ (Fig. 4 ). It should be noted that there is an evident tendency for reduction of the sulfur content with the increase in the fraction size, which described in a statistically significant (P-value $=0.00)$ and highly satisfactory manner by the non-linear model of dependence (Fig. 5) with a very high coefficient of determination $\mathrm{R}^{2}=97.3 \%$.

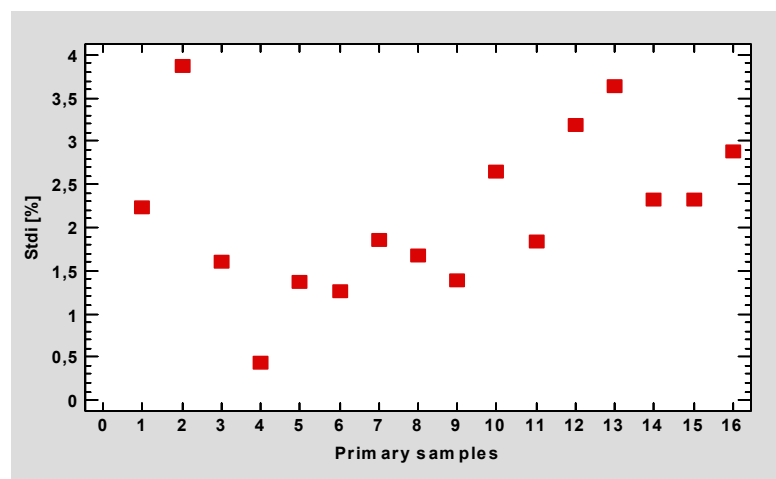

Figure 3. Plots of the total sulfur contents in the 16 primary samples (Stdi - the sulfur content $\left(\mathrm{S}_{\mathrm{t}}{ }^{\mathrm{d}}\right)$ in the individual samples).

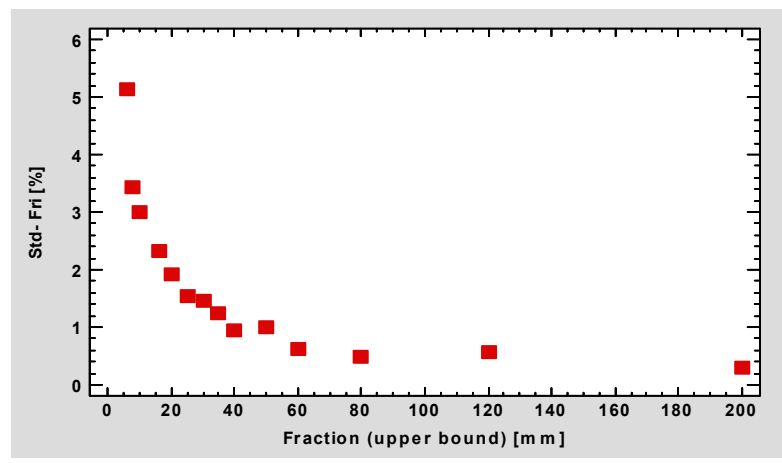

Figure 4. Plots of the total sulfur contents in the 14 fractions of 16 primary samples (Std-Fri - the sulfur content $\left(\mathrm{St}_{\mathrm{t}}^{\mathrm{d}}\right)$ in the individual fractions).

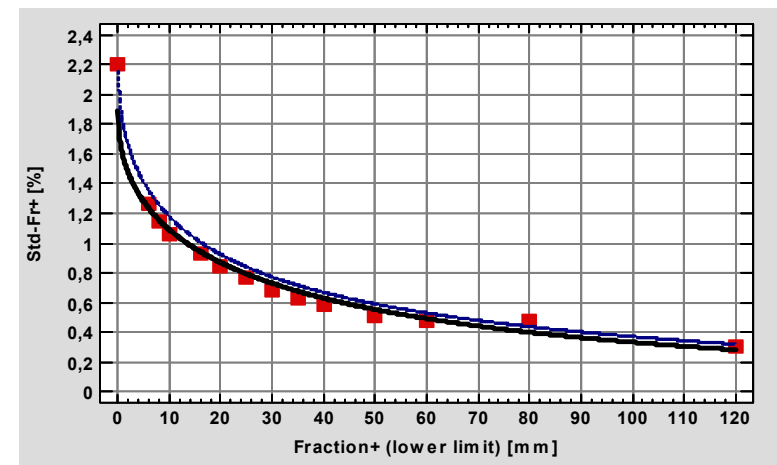

Figure 5. The graph of the best fitted model (solid line) of empirical dependence between the sulfur content and the lower limit of fraction of material (dashed line - upper confidence bound for probability level $\mathrm{P}=0.99$ );

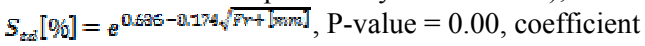
of determination $\mathrm{R}^{2}=97.3 \%$,

(Std-Fr+ - the sulfur content $\left(\mathrm{S}_{t} \mathrm{~d}\right)$ in the cumulative fractions above grain diameter).

The variability of the sulfur content in the primary samples is large, and when measured by the coefficient of variation is at $56 \%$. The Shapiro-Wilk's test does not give grounds to reject the hypothesis of normal distribution of the sulfur content (at the significance level of 0.05 ). Average sulfur content in the primary samples is $1.79 \%$ and goes significantly beyond the reference value of $1 \%$ permissible for inert mining waste. Given the increasing trend of the sulfur content with decreasing size of fractions (Fig. 4), it can be expected that after removal of the finer fractions of the material, the sulfur content in the remaining (thicker) portion of the rock material will be less than $1 \%$.

The conducted statistical analysis showed that only after the separation of the fraction finer than $16 \mathrm{~mm}$, the average sulfur content in the 16 primary samples has a value of less than $1 \%$, and in this case is $0.93 \%$ (Tab. 1). There is no guarantee, however, that it will stay below the limit (permissible value) of the sulfur content in subsequent batches of the waste rock material because of its relatively high volatility. For this purpose, the sulfur content in the rock material after elimination of subsequent fractions ( $<20$ and $<25 \mathrm{~mm})$ was also calculated. The Shapiro-Wilk's test (for the level of significance of 0.05 ) does not give grounds to reject the hypothesis of normal distribution of the sulfur content in other rock material of the fractions $>16,>20$ and $>25$ $\mathrm{mm}$. The variability of the sulfur content is still high and is at about $40 \%$.

To determine the minimum size of the fraction above which the probability of exceeding the average sulfur content will be small and will not exceed the adopted value of 0.01 , three statistical techniques were used, including:

- defining the upper limit of the confidence interval for the average sulfur content with the risk of exceeding it being less than 0.01 ,

- the use of the Student's t-test to verify the null hypothesis that the average sulfur content is equal to $1 \%$ against the alternative hypothesis that it is less than $1 \%$, 
- using the upper confidence limit for the non-linear model of dependence binding the sulfur content with the lower limits of the fractions (Fig. 5).

Table 1. Statistics of the total sulfur contents in distinguished fractions of combined 16 primary samples.

\begin{tabular}{|l|c|c|c|}
\hline $\begin{array}{l}\text { Statistics of sulfur } \\
\text { content }\end{array}$ & $\begin{array}{c}\text { Fraction } \\
>16 \\
{[\mathrm{~mm}]}\end{array}$ & $\begin{array}{c}\text { Fraction } \\
>20 \\
{[\mathrm{~mm}]}\end{array}$ & $\begin{array}{c}\text { Fraction } \\
>25 \\
{[\mathrm{~mm}]}\end{array}$ \\
\hline Arithmetic mean [\%] & 0.93 & 0.85 & 0.78 \\
\hline Coeff. of variation [\%] & 38 & 39 & 43 \\
\hline $\begin{array}{l}\text { Minimum/Maximum } \\
{[\%]}\end{array}$ & $0.28 / 1.44$ & $0.27 / 1.32$ & $0.23 / 1.19$ \\
\hline $\begin{array}{l}\text { Upper confidence bound } \\
\text { for } \mathrm{S}_{\mathrm{t}} \text { mean content [\%] } \\
\text { (probability level } \mathrm{P}=0.99 \text { ) }\end{array}$ & 1.16 & 1.06 & 0.997 \\
\hline $\begin{array}{l}\mathrm{t} \text {-test: P-value } \\
\text { Null hypothesis: mean } \\
\mathrm{S}_{\mathrm{t}}{ }^{\mathrm{d}}=1.0[\%] \\
\text { Alternative hypothesis: } \\
\text { mean } \mathrm{S}_{\mathrm{t}}{ }^{\mathrm{d}}<1 \% \text { [\%] }\end{array}$ & 0.216 & 0.043 & 0.009 \\
\hline $\begin{array}{l}\text { Upper confidence bound } \\
\text { for } \mathrm{S}_{\mathrm{t}}{ }^{\mathrm{d}} \text { contents [\%] } \\
\text { predicted from fitted model } \\
\text { for } \mathrm{P}=0.99 \text { (Fig. 5) }\end{array}$ & 1.01 & 0.93 & 0.84 \\
\hline
\end{tabular}

The applied approaches give very similar but not identical results (Tab. 1), which is associated with a certain variation of the masses of samples and fractions. It should be noted, however, that beginning with the fraction $>25 \mathrm{~mm}$ - all 3 methods agreeably show that the probability of exceeding the reference sulfur content of $1 \%$ is less than 0.01 . It can therefore be assumed that the boundary of separation of the fraction equal to $25 \mathrm{~mm}$ is suitable for "safe" distinguishing of fractions meeting one of the most important requirements for inert waste mining.

\section{The sulfur content in the secondary samples}

To verify the results of statistical analysis, which allowed for identifying the lower limit of the grain size, after the rejection of which it is possible to obtain material with low total sulfur content, the analysis focused on the secondary samples, in order to determine the value of the basic studied parameter. The secondary samples no. 4 to 16 were formed as a result of the rejection of fines with a diameter of $<20 \mathrm{~mm}$. Static batch test of contaminants leaching at 1:10 was conducted to determine the content of individual elements in the leachable form which may potentially be introduced into the aquatic environment (Tab. 2). For samples 1 to 3 the secondary samples were not prepared because of insufficient amount of material in the individual fractions. The obtained results were compared with the permissible parameters for waste water, according to [24] and with the permissible values for surface and groundwater in accordance with the regulations issued under the Water Act $[25,26$, 27]. The results were additionally compared with the criteria for waste admitted to inert waste landfills
[28], as a complement to the classification of inert mining waste [20], to which the analyzed aggregate relates for the purposes of this work. The results obtained in the contaminants leaching test indicate that the tested samples (after the rejection of fines) will not introduce abnormal amounts of sulfates in relation to qualifying the waste for inert waste landfill. The limit value set out by the above-mentioned regulation [28] is $1000 \mathrm{mg} / \mathrm{kg}$, while the values obtained in the leaching tests were in the range of $258-862 \mathrm{mg} / \mathrm{kg}$ on dry matter (based on Tab. 2). On the other hand, with regard to the solutions quality test (water extracts 1:10) the measured sulfates content is within the acceptable limits for wastewater. With respect to the limit values for the quality of surface water intended for human consumption [25], to the classification of groundwater quality [26], as well as to the classification of surface water quality [27], in no case exceeding of water quality was observed.

Table 2. The total content of sulfur and sulfates leachability in the secondary samples from the Janina Mine aggregates.

\begin{tabular}{|c|c|c|c|}
\hline $\begin{array}{c}\text { Secondary } \\
\text { samples } \\
\text { Fraction } \\
>20 \text { [mm] }\end{array}$ & $\begin{array}{c}\text { Neutralizing } \\
\text { potential } \\
\text { ratio NPR }\end{array}$ & $\begin{array}{c}\text { S total }\left(\mathrm{S}_{\mathrm{t}}{ }^{\mathrm{d}}\right) \\
{[\%] \mathrm{DM}}\end{array}$ & $\begin{array}{c}\mathrm{SO}_{4}{ }^{2-} \\
\text { batch tests } \\
1: 10 \\
{\left[\mathrm{mg} / \mathrm{dm}^{3}\right]^{*}}\end{array}$ \\
\hline Sample 4 & 40.00 & 0.038 & 52.47 \\
\hline Sample 5 & 8.00 & 0.202 & 49.35 \\
\hline Sample 6 & 1.16 & 1.383 & 71.46 \\
\hline Sample 7 & 3.08 & 0.520 & 35.37 \\
\hline Sample 8 & 6.15 & 0.262 & 31.02 \\
\hline Sample 9 & 4.32 & 0.373 & 57.21 \\
\hline Sample 10 & 4.21 & 0.382 & 86.22 \\
\hline Sample 11 & 5.33 & 0.295 & 26.25 \\
\hline Sample 12 & 3.64 & 0.438 & 31.05 \\
\hline Sample 13 & 2.42 & 0.663 & 25.83 \\
\hline Sample 14 & 2.81 & 0.571 & 57.27 \\
\hline Sample 15 & 3.20 & 0.500 & 46.86 \\
\hline Sample 16 & 1.95 & 0.816 & 84.66 \\
\hline
\end{tabular}

* $\mathrm{pH}$ of the solutions of 7.7-8.1

DM - dry matter

In the light of the results of neutralization potential ratio NPR in the secondary samples (Tab. 2) it was concluded that the maximum content of sulfide sulfur in the secondary samples may be required at $1 \%$. This parameter expresses the ability of the tested aggregates to neutralize the acidity of the environment caused by the potential decay of sulfide minerals. For the secondary samples created from the combination of grains with a diameter $>20 \mathrm{~mm}$, in most cases this value is greater than 3 . Only in individual cases, 
the value is slightly lower. It should be noted that the average rate of neutralizing potential ration, as calculated for the whole batch of the analyzed secondary samples is 2-fold higher than 3 and is equal to 6.63 . In the secondary samples with grain size greater than $20 \mathrm{~mm}$ exceedance of the limit value adopted for the total sulfur content is not observed, beyond the sole exception of sample 6, where the sulfur content reaches $1.4 \%$.

To clarify the issue of occurrence of much higher sulfur contents in the fine fractions, an analysis of forms of sulfur occurrence in the surveyed samples was conducted (Tab. 3). Observations for the averaged samples were conducted using scanning electron microscopy (SEM, AGH Laboratory for Phase, Structural and Textural Research). Sulfur compounds identified using this method in all tested samples are found to be pyrite. The form of pyrite occurrence in all tested samples is similar (irregular fragments of most likely larger crystals). Spread in the distribution of the pyrite fragments is relatively small, and the majority of tested fragments has a size of several tens of micrometers. There are also smaller objects, having a size less than 10 micrometers. Only in the analyzed fraction of sample 5 framboid pyrite was observed, with crystal size of about 1 micrometer. No other sulfide or sulfate minerals were found in any of the analyzed samples. For the same analyzed fractions another study of the total sulfur content using high-temperature method was conducted (Chemical Laboratory of the Department of Forest Ecology and Reclamation in the University of Agriculture in Krakow).

Table 3. The form of sulfur occurrence and its content in the selected fractions of the aggregate from the Janina Mine.

\begin{tabular}{|c|c|c|}
\hline $\begin{array}{c}\text { The fraction separated } \\
\text { in the sample }\end{array}$ & $\begin{array}{c}\mathrm{S} \text { total } \\
\left(\mathrm{S}_{\mathrm{t}}^{\mathrm{a}}\right)[\%]\end{array}$ & Form of sulfur \\
\hline $\begin{array}{c}\text { Fraction } 0-6 \mathrm{~mm} \\
\text { sample } 8\end{array}$ & 4.766 & pyrite \\
\hline $\begin{array}{c}\text { Fraction 0-6 } \mathrm{mm} \\
\text { sample 13 }\end{array}$ & 8.709 & pyrite \\
\hline $\begin{array}{c}\text { Fraction 8-10 mm } \\
\text { sample 14 }\end{array}$ & 5.703 & pyrite \\
\hline $\begin{array}{c}\text { Fraction 50-60 mm } \\
\text { sample 5 }\end{array}$ & 0.125 & $\begin{array}{c}\text { pyrite, } \\
\text { framboid pyrite }\end{array}$ \\
\hline $\begin{array}{c}\text { Fraction 50-60 } \mathrm{mm} \\
\text { sample 6 }\end{array}$ & 2.050 & pyrite \\
\hline $\begin{array}{c}\text { Fraction 60-80 } \mathrm{mm} \\
\text { sample 12 }\end{array}$ & 0.335 & pyrite \\
\hline
\end{tabular}

The conducted study showed a high content of pyritic sulfur in the fine fractions $0-6$ and $8-10 \mathrm{~mm}$ in excess of $5 \%$. The coarser fractions had low total sulfur content, thus confirming the results obtained in the previous step of the work for particular fractions sieved from the raw samples.

\section{Summary and conclusions}

The study confirmed the role of sulfur, as the most important and characteristic parameter that determines where and under what conditions, the use of waste rock as raw material and/or mining waste is possible. In the process of reclamation of open-pit mining objects with simultaneous filling of the mined pits, each time it is necessary to conduct a broad analysis of the quality of the material and the conditions of the project location. It is important to relate the results of research to the legal requirements applicable to both mining waste as well as to the quality and protection of soil and water environment. The studies of sulfur content in the samples should be carried out in appropriate number and periodicity, allowing for obtaining the best results, that relate to the entire batch of material.

The study analyzed the sulfur in numerous samples of aggregate as both total content and in the leachable form. It has been shown that there is a possibility of selecting aggregate fractions safe for the environment if using the percentage content of sulfur in the aggregates and the concentration of sulfate in the static pollutants leaching tests as the main criteria for assessment, supplemented by testing of the aggregates buffering abilities (study of the neutralizing potential ratio). The conducted studies of total sulfur content in the secondary samples has shown that the best quality parameters for waste rock from Janina Mine are found in the aggregates deprived of the fine fractions. Based on the conducted study, the grain diameter of $20 \mathrm{~mm}$ can be considered as the lower limit, above which the materials will have appropriately low sulfur content. The statistical analysis showed similar results but simultaneously displays that even higher safety (with the risk of error <0.01) for the soil and water environment can be achieved using a lower limit of grain diameter of $25 \mathrm{~mm}$.

The applied statistical evaluation of the results of the sulfur content in the individual fractions, allows for estimating the extent to which the results of the primary samples are close to the actual values obtained in the laboratory conditions for the secondary samples. The laboratory studies also indicate the possibility of seeking lower limit of the grain diameter above which the material will have low sulfur content, which will be continued in subsequent works.

\section{Acknowlegements}

The authors thank TAURON Wydobycie S.A. in Jaworzno for providing data and enabling the conduct of this paper. The publication was carried out partly in the framework of the statutory works of MEERI PAS.

\section{References}

1. K. Galos, J. Szlugaj, Górnictwo Odkrywkowe, 51(2), 25-31 (2010) 
2. K. Galos, J. Szlugaj, Gospodarka Surowcami Mineralnymi - Mineral Resources Management, 30(4), 51-64 (2014)

3. A. Szymkiewicz, A. Fraś, R. Przystaś, Wiadomości Górnicze, 7-8, 435-441 (2009)

4. J. Wróbel, A. Fraś, T. Pierzchała, R. Przystaś, A. Machnik, J.J. Hycnar, In: Proceedings of the XXVI-th Conf. „Zagadnienia surowców energetycznych $i$ energii $w$ gospodarce krajowej", 113-127 (2012)

5. P. Strzałkowski, U. Kaźmierczak, Mining Science Mineral Aggregates, 21(1), 203-213 (2014)

6. S. Góralczyk Ed., Gospodarka surowcami odpadowymi $z$ węgla kamiennego (IMBiGS Warszawa, 2011)

7. K. Bojarska, Z. Bzowski, Górnictwo i Geologia, 7(2), 101-113 (2012)

8. S. Góralczyk, I. Baic, Polityka Energetyczna Energy Policy Journal, 12(2/2), 145-157 (2009)

9. I. Baic, B. Witkowska-Kita, Rocznik Ochrona Środowiska (Annual Set The Environment Protection), 13, 1315-1326 (2011)

10. Z. Korban, Górnictwo i Geologia, 6(1), 109-120 (2011)

11. B. Klojzy-Karczmarczyk, J. Mazurek, Zeszyty Naukowe IGSMiE PAN, 90, 67-78 (2015)

12. I. Twardowska, J. Szczepańska, S. Witczak, Wptyw odpadów górnictwa węla kamiennego naśrodowisko wodne. Ocena zagrożenia, prognozowanie, zapobieganie, (Prace i Studia 35, 1988)

13. S. Witczak, A. Postawa, In: Proceedings of the Fourth Intern. Sym. on the Reclamation, Treatment and Utilization of Coal Mining Wastes, 1, 37-44 (1993)

14. J. Szczepańska, J. Krawczyk, Gospodarka Surowcami Mineralnymi - Mineral Resources Management, 9(3), 529-546 (1993)

15. B. Klojzy-Karczmarczyk, Zastosowanie odpadów energetycznych $w$ ograniczaniu transportu zanieczyszczeń ze składowisk odpadów górniczych, (Studia, Rozprawy, Monografie 117, 2003)

16. B. Klojzy-Karczmarczyk, J. Mazurek, Polityka Energetyczna - Energy Policy Journal, 17(4), 289302 (2014)

17. J. Mucha, M. Wasilewska, Gospodarka Surowcami Mineralnymi - Mineral Resources Management, 21(1), 5-21 (2005)

18. Z. Kokesz, Gospodarka Surowcami Mineralnymi Mineral Resources Management, 26(3), 95-110 (2010)

19. Cz. Rosik-Dulewska, Podstawy gospodarki odpadami, 5-th ed. (PWN, 2012)

20. Dz. U. [Journal of Law] of 2011, No. 175, Item 1048 (www.isap.sejm.gov.pl)

21. B. Klojzy-Karczmarczyk, J. Mazurek, K. Paw, Gospodarka Surowcami Mineralnymi - Mineral Resources Management (to be published, 2016)

22. Polish Norm PN-EN 15875, PKN Warszawa (2011)

23. Polish Norm PN-EN 12457-4, PKN Warszawa (2006)
24. Dz. U. [Journal of Law] of 2014, Item 1800 (www.isap.sejm.gov.pl)

25. Dz. U. [Journal of Law] of 2002, No. 204, Item 1728 (www.isap.sejm.gov.pl)

26. Dz. U. [Journal of Law] of 2016, Item 85 (www.isap.sejm.gov.pl)

27. Dz. U. [Journal of Law] of 2014, Item 1482 (www.isap.sejm.gov.pl)

28. Dz. U. [Journal of Law] of 2015, Item 1277 (www.isap.sejm.gov.pl) 